\title{
Biosynthesis of Two Dihydropyrrole-Polyketides from a Marine-Derived Penicillium citrinum
}

\author{
Stelamar Romminger, ${ }^{a}$ Eli F. Pimenta, ${ }^{a}$ Eduardo S. Nascimento, ${ }^{b}$ \\ Antonio G. Ferreira ${ }^{b}$ and Roberto G. S. Berlinck*,a \\ ${ }^{a}$ Instituto de Química de São Carlos, Universidade de São Paulo, CP 780, 13560-970 São Carlos-SP, Brazil \\ ${ }^{b}$ Departamento de Química, Universidade Federal de São Carlos, 13565-905 São Carlos-SP, Brazil
}

Experimentos de incorporação com precursores marcados com ${ }^{13} \mathrm{C}$ foram realizados objetivando-se estabelecer a biossíntese de dois dihidropirróis $N$-acilados, (8E)-1-(2,3-dihidro1H-pirrol-1-il)-2-metildec-8-eno-1,3-diona (1) e 1-(2,3-dihidro-1H-pirrol-1-il)-2-metildecano1,3-diona (2), isolados de culturas de Penicillium citrinum de origem marinha. A biossíntese de ambos, $\mathbf{1}$ e $\mathbf{2}$, procede através da incorporação de acetato, metionina e ornitina.

Feeding experiments with ${ }^{13} \mathrm{C}$-labeled precursors were performed in order to establish the biosynthesis of two $\mathrm{N}$-acylated dihydropyrroles, (8E)-1-(2,3-dihydro-1H-pyrrol-1-yl)-2-methyldec8-ene-1,3-dione (1) and 1-(2,3-dihydro-1H-pyrrol-1-yl)-2-methyldecane-1,3-dione (2), isolated from the cultures of a marine-derived Penicillium citrinum. The biosynthesis of both, $\mathbf{1}$ and $\mathbf{2}$, involves the incorporation of acetate, methionine and ornithine.

Keywords: Penicillium citrinum, marine-derived fungus, mixed biosynthesis, dihydropyrrole

\section{Introduction}

Pyrrole, dihydropyrrole (pyrroline) and tetrahydropyrrole (pyrrolidine) alkaloids constitute a unique class of secondary metabolites, which include several bioactive members such as the tropane alkaloids, ${ }^{1}$ tambjamines ${ }^{2-4}$ and prodigiosin, ${ }^{5}$ anatoxin-a, ${ }^{6}$ as well as 2 -alkyl or 2,5-dialkyl-branched pyrrolidine and pyrroline ant chemical defenses. ${ }^{7}$ However, such alkaloids are extremely rare in fungi, the only examples found in literature ${ }^{8}$ include the dihydropyrrole-bearing peptide brevigellin isolated from
Penicillium brevicompactum, ${ }^{9}$ the dihydropyrrole $\beta$-keto amides $\mathbf{1}$ and $\mathbf{2}$ also isolated from $P$. brevicompactum, ${ }^{10-12}$ the mildly antibiotic scalusamides A-C (3-5), which have been isolated from a marine-derived $P$. citrinum, ${ }^{13}$ as well as the tetrahydropyrrole-citrinin conjugate perinadine A, isolated from $P$. citrinum of marine origin. ${ }^{14}$

Compounds $\mathbf{1}$ and $\mathbf{2}$ display insecticidal, fungicidal activities and induce precocious metamorphosis in the milkweed bug Oncopeltus fasciatus (Insecta). ${ }^{12} \mathrm{We}$ have recently isolated the same compounds $\mathbf{1}$ and $\mathbf{2}$ from a marine-derived $P$. citrinum, ${ }^{15}$ and became interested to<smiles></smiles><smiles>CCCCCCCC(=O)C(C)C(=O)N1C=CCC1</smiles>

2<smiles>C/C=C/CCCCC(=O)C(C)C(=O)N1C=CC[C@H]1CO</smiles><smiles>CCC/C=C/CCC(=O)C(C)C(=O)N1C=CC[C@H]1CO</smiles><smiles>CCCCCCCC(=O)C(C)C(=O)N1C=CC[C@H]1CO</smiles>

*e-mail: rgsberlinck@iqsc.usp.br 
establish the actual biosynthetic pathway leading to $\mathbf{1}$ and 2. This is because while pyrrole, dihydropyrrole or pyrrolidine alkaloids isolated from non-fungal sources are typically derived from proline, ${ }^{16,17}$ ornithine, ${ }^{1}$ or even from acetate ${ }^{16}$ the biosynthesis of the above mentioned dihydropyrroles isolated from fungi have not yet been investigated. Particularly, we aimed to verify if the dihydropyrrole moiety in $\mathbf{1}$ and $\mathbf{2}$ is derived from proline or ornithine, and if the branched moiety is derived from propionate or from acetate plus methionine. To the best of our knowledge, this is the first report on the biosynthesis of fungal dihydropyrrole-bearing secondary metabolites.

\section{Results and Discussion}

After toxicity evaluation with unlabeled sodium acetate, added to the growth medium of $P$. citrinum (up to $5 \mathrm{~g} \mathrm{~L}^{-1}$ ), for which no morphology alterations of the fungus in the growth medium or even alterations in the production yield of 1 and $\mathbf{2}$ were observed, experiments with sodium $\left[1{ }^{13} \mathrm{C}\right]$ acetate, sodium $\left[1,2-{ }^{13} \mathrm{C}_{2}\right]$ acetate, sodium $[2,3-$ $\left.{ }^{13} \mathrm{C}_{2}\right]$ propionate, $\left[\right.$ methyl- $\left.{ }^{13} \mathrm{C}\right]$ methionine, $\left[\mathrm{U}-{ }^{13} \mathrm{C}_{5}\right]$ ornithine and $\left[\mathrm{U}-{ }^{13} \mathrm{C}_{5}\right]$ proline were performed. ${ }^{13} \mathrm{C}$-Labeled precursors were added at the fourth day of growth, at a final concentration of $1 \mathrm{mg} \mathrm{mL}^{-1}$ for each precursor, using previously optimized growth conditions. ${ }^{15}$ Separate growth experiments were performed without the addition of labeled precursors as control. Cultures were harvested after 14 days for each growth experiment using distinct ${ }^{13} \mathrm{C}$-labeled precursors. After growth media filtration and solid phase extraction, fractions were evaporated and subjected to HPLC-UV-ESI-MS analysis.

Preliminary small-scale experiments in $50 \mathrm{~mL}$ of growth media for each ${ }^{13} \mathrm{C}$-labeled precursor gave, after the growth media clean-up, fractions containing both $\mathbf{1}$ and $\mathbf{2}$ which clearly showed the incorporation of sodium $\left[1-{ }^{13} \mathrm{C}\right]$ acetate, sodium $\left[1,2-{ }^{13} \mathrm{C}_{2}\right.$ ] acetate, $\left[\right.$ methyl $\left.-{ }^{13} \mathrm{C}\right]$ methionine and of $\left[\mathrm{U}^{13} \mathrm{C}_{5}\right.$ ] ornithine by HPLC-UV-MS analyses. Clusters at $\mathrm{m} / \mathrm{z}, 250$ for the $[\mathrm{M}+\mathrm{H}]^{+}$ion and at $m / z, 272$ for the $[\mathrm{M}+\mathrm{Na}]^{+}$ ion were observed (see Supplementary Information). The preliminary experiments with sodium $\left[2,3-{ }^{13} \mathrm{C}_{2}\right]$ propionate and $\left[\mathrm{U}_{-13}{ }^{13} \mathrm{C}_{5}\right.$ ]proline showed no incorporation in both 1 and 2. Therefore, large-scale feeding experiments with ${ }^{13} \mathrm{C}$-labeled acetate, ornithine and methionine were performed in order to obtain sufficient amounts of labeled $\mathbf{1}$ and $\mathbf{2}$ for ${ }^{13} \mathrm{C}$ NMR analyses.

Separate $P$. citrinum growth experiments in a total volume of approximately $1.4 \mathrm{~L}$ were performed using sodium $\left[1-{ }^{13} \mathrm{C}\right]$ acetate, sodium $\left[1,2-{ }^{13} \mathrm{C}_{2}\right]$ acetate, [methyl $\left.-{ }^{13} \mathrm{C}\right]$ methionine and $\left[\mathrm{U}-{ }^{13} \mathrm{C}_{5}\right]$ ornithine (see Experimental). After growth in the presence of the labeled precursors, solid-phase extraction of the growth media and extensive purification of both $\mathbf{1}$ and $\mathbf{2}$ by HPLC, ${ }^{13} \mathrm{C}$ NMR analyses clearly showed the incorporation of the labeled precursors. $P$. citrinum grown in medium enriched with sodium $\left[1-{ }^{13} \mathrm{C}\right]$ acetate gave, after isolation, compound $\mathbf{1}$ with significant incorporation at C-6 $(\delta$ 166.2), C-8 $(\delta 206.3), \mathrm{C}-10(\delta 22.5), \mathrm{C}-12(\delta 31.7)$ and $\mathrm{C}-14(\delta 124.5)$, in agreement with a pattern expected for an acetate-derived polyketide chain (Table 1 and Figure S3 in Supplementary Information). An additional feeding experiment with sodium $\left[1,2-{ }^{13} \mathrm{C}_{2}\right]$ acetate confirmed this result, indicating that the $\beta$-keto-amide chains in $\mathbf{1}$ and $\mathbf{2}$ are derived from acetate. The incorporation ratio of sodium $\left[1,2-{ }^{13} \mathrm{C}_{2}\right]$ acetate into 1 was calculated as previously proposed by Kubanek and Andersen. ${ }^{18}$ We measured the incorporation rate at the amide carbonyl group (C-6) and at the terminal methyl group of the alkyl chain (C-15) as 12.7 and $11.7 \%$, respectively (Table 1; see also Figures S6 to S10).

Although propionate is considered as toxic for fungi, ${ }^{19-21}$ in few instances it has been demonstrated that labeled propionate was incorporated into fungal polyketides..$^{22,23}$ Therefore, in principle the incorporation of propionate into $\mathbf{1}$ and $\mathbf{2}$ could not be ruled out. We have not verified sodium $\left[2,3-{ }^{13} \mathrm{C}_{2}\right]$ propionate incorporation into 1 and 2 (data not shown). The C-16 methyl group was clearly methionine-derived, confirmed after a feeding experiment with $\left[\right.$ methyl $\left.-{ }^{13} \mathrm{C}\right]$ methionine that showed a very significative incorporation at C-16 $(\delta$ 12.7; see Table 1 and Figure S12). The feeding experiment with $\left[\mathrm{U}-{ }^{13} \mathrm{C}_{5}\right]$ proline showed no incorporation into $\mathbf{1}$ and $\mathbf{2}$. On the other hand, feeding with $\left[\mathrm{U}_{-}{ }^{13} \mathrm{C}_{5}\right]$ ornithine showed marked incorporation at the dihydropyrrole group, for which ${ }^{13} \mathrm{C}-{ }^{13} \mathrm{C}$ coupling constants of the dihydropyrrole moiety could be unambiguously measured: $74 \mathrm{~Hz}$ for C-2/C-3, 36 for C-3/C-4, 36 for C-4/C-5 and 7 for C-2/C-5 (Figures S14 to S16). Since compound 2 has been isolated as a minor derivative, ${ }^{15}$ some of the feeding experiments gave insufficient amounts of labeled $\mathbf{2}$ to obtain reliable ${ }^{13} \mathrm{C}$ NMR spectra to measure the incorporation rates of $\left[1,2-{ }^{13} \mathrm{C}_{2}\right]$ acetate and of $\left[\mathrm{U}-{ }^{13} \mathrm{C}_{5}\right]$ ornithine. The results obtained evidenced that both $\mathbf{1}$ and $\mathbf{2}$ are derived from acetate, ornithine and methionine.

The dihydropyrrole moiety of $\mathbf{1}$ and $\mathbf{2}$ did not show incorporation of labeled acetate. This result was surprising, considering that ornithine is biosynthetically derived from arginine, itself originary from $\alpha$-ketoglutarate via glutamate in the urea cycle. ${ }^{24}$ An additional growth experiment with $P$. citrinum in starch and unlabeled sodium acetate was performed in order to double check this result. No production of $\mathbf{1}$ and $\mathbf{2}$ was observed, as expected, since fungi require exogenous nitrogen sources. ${ }^{24}$ Therefore, we 
Table 1. Incorporation ratios of ${ }^{13} \mathrm{C}$-labeled precursors into dihydropyrrole $\mathbf{1}$

\begin{tabular}{|c|c|c|c|c|c|}
\hline Position & ${ }^{13} \mathrm{C}^{\mathrm{a}}$ & {$\left[1-{ }^{13} \mathrm{C}_{1}\right] \mathrm{AcONa}$} & {$\left[1,2-{ }^{13} \mathrm{C}_{2}\right] \mathrm{AcONa}$} & {$\left[\right.$ methyl- ${ }^{13} \mathrm{C}_{1}$ ] methionine } & {$\left[\mathrm{U}-{ }^{13} \mathrm{C}_{5}\right.$ ] ornithine } \\
\hline 1 & - & - & - & - & - \\
\hline 2 & 129.4 & 1.15 & 1.25 & 0.94 & 10.18 \\
\hline 3 & 111.9 & 1.1 & 1.1 & 1.1 & 15.02 \\
\hline 4 & 27.7 & 0.92 & 0.7 & 0.77 & 13.67 \\
\hline 5 & 44.9 & 1.48 & 0.69 & 0.84 & 13.14 \\
\hline 6 & 166.2 & 10.55 & 15.35 & 0.84 & 1.3 \\
\hline 7 & 50.5 & 0.79 & 7.39 & 0.38 & 0.76 \\
\hline 8 & 206.3 & 8.87 & 13.17 & 1.1 & 1.37 \\
\hline 9 & 39.9 & nd & nd & nd & nd \\
\hline 10 & 22.5 & 8.34 & 10.28 & 0.65 & 0.56 \\
\hline 11 & 28.3 & 0.88 & 8.5 & 0.62 & 0.47 \\
\hline 12 & 31.7 & 8.46 & 9.24 & 0.68 & 0.55 \\
\hline 13 & 131 & 1.25 & 7.83 & 0.57 & 0.52 \\
\hline 14 & 124.5 & 8.06 & 7.54 & 0.61 & 0.62 \\
\hline 15 & 17.7 & 1.13 & 7.56 & 0.56 & 0.44 \\
\hline 16 & 12.7 & 0.89 & 0.66 & 28.24 & 1.29 \\
\hline
\end{tabular}

${ }^{\text {a }}{ }^{13}$ NMR spectra recorded in DMSO- $d_{6}$ at $100.1 \mathrm{MHz}$; nd: not detected.

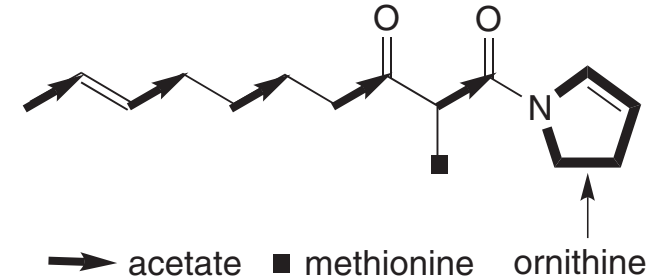

Scheme 1. Biosynthetic precursors incorporated into (8E)-1-(2,3-dihydro$1 H$-pyrrol-1-yl)-2-methyldec-8-ene-1,3-dione (1).

assumed that the biosynthesis of the dihydropyrrole moiety in $\mathbf{1}$ and $\mathbf{2}$ needs ornithine, but not proline, as precursor.

\section{Conclusions}

We have unambiguously established the biosynthetic origin of dihydropyrroles $\mathbf{1}$ and $\mathbf{2}$ as derived from acetate, methionine and ornithine. However, the sequence of events leading to compounds $\mathbf{1}$ and $\mathbf{2}$ in Penicillium citrinum still has to be established.

\section{Experimental}

\section{General procedures}

NMR spectra were recorded on a Bruker ARX 9.4T instrument, operating at $100.10 \mathrm{MHz}$ for ${ }^{13} \mathrm{C}$ channels, at $25{ }^{\circ} \mathrm{C}$ using TMS as internal reference. Solvents used for extraction and chromatography were HPLC-grade solvents. HPLC separations were performed either with a Waters quaternary pump 600 , double beam UV detector 2487 , and data module 746, or with a Waters 600E system controller liquid chromatography attached to a Waters 996 photodiode array detector, on which the UV spectra have been recorded as well. HPLC-UV-MS analysis were performed using a Waters Alliance 2695 coupled on-line with a Waters 2996 photodiode array detector, followed by a Micromass ZQ2000 mass spectrometry detector with an electrospray interface. The photodiode array scanned the samples at $\lambda_{\max } 230$ and $254 \mathrm{~nm}$. The mass spectrometer detector was optimized using the following conditions: capillary voltage, $3.00 \mathrm{kV}$; source block temperature, $100{ }^{\circ} \mathrm{C}$; desolvation temperature, $350{ }^{\circ} \mathrm{C}$; voltage cone, $25 \mathrm{~V}$; electrospray, positive mode; detection range, 200-550 Da with total ion count extracting acquisition. Cone and desolvation gas flow were at 50 and $350 \mathrm{~L} \mathrm{~h}^{-1}$, respectively, using a Nitrogen Peak Scientific N110DR as a nitrogen source. Data acquisition and processing were performed using Empower 2.0.

Microbial strain

The P. citrinum strain was isolated from a seaweed (Caulerpa sp.). ${ }^{11}$ P. citrinum $\mathrm{F} 53$ strain have been deposited in the CBMAI collection under the accession number CBMAI 1186.

Small scale incorporation experiments with ${ }^{13} \mathrm{C}$-labeled precursors

Fifty $\mathrm{mL}$ of sterilized and modified MF fermentation media (12 g L $\mathrm{g}^{-1}$ glucose; $6.0 \mathrm{~g} \mathrm{~L}^{-1}$ starch; $12.0 \mathrm{~g} \mathrm{~L}^{-1}$ soytone; $3.0 \mathrm{~g} \mathrm{~L}^{-1}$ peptone; $0.18 \mathrm{~g} \mathrm{~L}^{-1}$ meat extract; $3.0 \mathrm{~g} \mathrm{~L}^{-1}$ yeast 
extract) in artificial sea water (ASW: $0.27 \mathrm{~g} \mathrm{~L}^{-1} \mathrm{CaCl}_{2}$; $1.94 \mathrm{~g} \mathrm{~L}^{-1} \mathrm{MgCl}_{2} ; 0.12 \mathrm{~g} \mathrm{~L}^{-1} \mathrm{KCl} ; 6.0 \mathrm{~g} \mathrm{~L}^{-1} \mathrm{NaCl} ; 0.03 \mathrm{~g} \mathrm{~L}^{-1}$ $\mathrm{Na}_{2} \mathrm{HPO}_{4} ; 0.64 \mathrm{~g} \mathrm{~L}^{-1} \mathrm{NaSO}_{4} ; 0.034 \mathrm{~g} \mathrm{~L}^{-1} \mathrm{NaHCO}_{3}$; $0.020 \mathrm{~g} \mathrm{~L}^{-1} \mathrm{KBr} ; 0.008 \mathrm{~g} \mathrm{~L}^{-1} \mathrm{SrCl}_{2} ; 0.006 \mathrm{~g} \mathrm{~L}^{-1} \mathrm{H}_{3} \mathrm{BO}_{3}$ ) were prepared in $250 \mathrm{~mL}$ Schott flasks, in duplicates for each incorporation experiment. Then, $10^{5}$ spores of a P. citrinum inoculum were inoculated in each Schott flask, followed by incubation at $30{ }^{\circ} \mathrm{C}$ for 14 days. ${ }^{13} \mathrm{C}$-labeled precursors (sodium $\left[1-{ }^{13} \mathrm{C}\right]$ acetate, sodium $\left[1,2-{ }^{13} \mathrm{C}_{2}\right]$ acetate, sodium $\left[2,3-{ }^{13} \mathrm{C}_{2}\right]$ propionate, $\left[\mathrm{U}-{ }^{13} \mathrm{C}_{5}\right]$ proline, $\left[\mathrm{U}-{ }^{13} \mathrm{C}_{5}\right]$ ornithine and $\left[\right.$ methyl $\left.-{ }^{13} \mathrm{C}\right]$ methionine) were added in a final concentration of $1 \mathrm{mg} \mathrm{mL}^{-1}$ on the fourth day of microbial growth. A separate culture without the addition of any precursor was incubated as a control. Cultures were harvested after 14 days of growth and filtered through celite. The liquid media of each growth experiment using distinct ${ }^{13} \mathrm{C}$-labeled precursors were separately subjected to a reversed-phase solid phase extraction using a $\mathrm{C}_{18}$ cartridge eluted with $100 \% \mathrm{H}_{2} \mathrm{O}$ (fraction 1, discarded), 1:1 $\mathrm{MeOH} / \mathrm{H}_{2} \mathrm{O}$ (fraction 2, F2) and $100 \% \mathrm{MeOH}$ (fraction 3, F3). Fractions F2 and F3 were collected, dried in vacuo and weighed. Aliquots of $1 \mathrm{mg}$ of each F2 and F3 were analyzed by HPLC-UV-MS using a reversed-phase $\mathrm{C}_{18}$ column $\left(\mathrm{X}\right.$-Terra $\left.{ }^{\circledR} \mathrm{MS}, 50 \times 2.1 \mathrm{~mm}, 3.5 \mu \mathrm{m}\right)$, eluted with a MeOH$/ \mathrm{H}_{2} \mathrm{O}$ gradient. Fractions collected from the growth experiments using sodium $\left[1-{ }^{13} \mathrm{C}\right]$ acetate, sodium $\left[1,2-{ }^{13} \mathrm{C}_{2}\right]$ acetate, $\left[\mathrm{U}-{ }^{13} \mathrm{C}_{5}\right]$ ornithine and $\left[\right.$ methyl- $\left.{ }^{13} \mathrm{C}\right]$ methionine showed incorporation. These experiments were selected to be repeated in a larger scale.

Large scale incorporation experiments with ${ }^{13} \mathrm{C}$-labeled precursors

A total volume of $1.4 \mathrm{~L}$ of culture media distributed in 14 Schott flasks with $100 \mathrm{~mL}$ each were inoculated with $10^{5}$ spores of $P$. citrinum, followed by incubation at $30{ }^{\circ} \mathrm{C}$ during 14 days. Growth experiments were performed using ${ }^{13} \mathrm{C}$-labeled precursors (sodium $\left[1-{ }^{13} \mathrm{C}\right]$ acetate, sodium $\left[1,2-{ }^{13} \mathrm{C}_{2}\right]$ acetate, $\left[\mathrm{U}-{ }^{13} \mathrm{C}_{5}\right]$ ornithine and $\left[\right.$ methyl $\left.{ }^{-13} \mathrm{C}\right]$ methionine), added at a final concentration of $1 \mathrm{mg} \mathrm{mL} \mathrm{m}^{-1}$ on the fourth day of microbial growth. Cultures were harvested after 14 days of growth and filtered through celite. The liquid media of identical growth experiments were pooled and subjected to a reversed-phase solid phase extraction using a $\mathrm{C}_{18}$ cartridge eluted with $100 \%$ $\mathrm{H}_{2} \mathrm{O}$ (fraction 1, discarded), 1:1 $\mathrm{MeOH} / \mathrm{H}_{2} \mathrm{O}$ (fraction 2, $\mathrm{F} 2$ ) and $100 \% \mathrm{MeOH}$ (fraction 3, F3). Fractions F2 and F3 were collected, dried in vacuo and weighed. A total amount of crude $\mathrm{F} 3$ fractions of each ${ }^{13} \mathrm{C}$-labeled precursor experiments were obtained: $78.3 \mathrm{mg}$ of experiment using sodium $\left[1-{ }^{13} \mathrm{C}\right]$ acetate; $40.4 \mathrm{mg}$ of experiment using sodium $\left[1,2-{ }^{13} \mathrm{C}_{2}\right]$ acetate; $79.2 \mathrm{mg}$ of experiment using $\left[\mathrm{U}-{ }^{13} \mathrm{C}_{5}\right.$ ] ornithine; $89.7 \mathrm{mg}$ of experiment using [methyl$\left.{ }^{13} \mathrm{C}\right]$ methionine. Each of these crude fractions was purified by HPLC-UV-MS using a reversed-phase $\mathrm{C}_{18}$ column (Inertsil ODS-3, $250 \times 4.6 \mathrm{~mm}, 5 \mu \mathrm{m}$ ), eluted with 7:3 $\mathrm{MeOH} / \mathrm{H}_{2} \mathrm{O}$. The following amounts of $\mathbf{1}$ and $\mathbf{2}$ obtained after each incorporation experiment were, respectively: 5.4 and $1.1 \mathrm{mg}$ using sodium $\left[1-{ }^{13} \mathrm{C}\right]$ acetate; 4.3 and $1.0 \mathrm{mg}$ using sodium $\left[1,2-{ }^{13} \mathrm{C}_{2}\right]$ acetate; 7.5 and $2.1 \mathrm{mg}$ using $\left[\mathrm{U}-{ }^{13} \mathrm{C}_{5}\right]$ ornithine; 4.0 and $1.0 \mathrm{mg}$ using $\left[\right.$ methyl $\left.-{ }^{13} \mathrm{C}\right]$ methionine.

\section{Small scale experiment with soluble starch and acetate}

Two growth experiments with a total volume of $50 \mathrm{~mL}$ of culture media each $\left(6 \mathrm{~g} \mathrm{~L}^{-1}\right.$ soluble starch; $2 \mathrm{~g} \mathrm{~L}^{-1}$ unlabeled sodium acetate; in ASW $\left(0.27 \mathrm{~g} \mathrm{~L}^{-1}\right.$ $\mathrm{CaCl}_{2} ; 1.94 \mathrm{~g} \mathrm{~L}^{-1} \mathrm{MgCl}_{2} ; 0.12 \mathrm{~g} \mathrm{~L}^{-1} \mathrm{KCl} ; 6.0 \mathrm{~g} \mathrm{~L}^{-1} \mathrm{NaCl}$; $0.03 \mathrm{~g} \mathrm{~L}^{-1} \mathrm{Na}_{2} \mathrm{HPO}_{4} ; 0.64 \mathrm{~g} \mathrm{~L}^{-1} \mathrm{NaSO}_{4} ; 0.034 \mathrm{~g} \mathrm{~L}^{-1}$ $\mathrm{NaHCO}_{3} ; 0.020 \mathrm{~g} \mathrm{~L}^{-1} \mathrm{KBr} ; 0.008 \mathrm{~g} \mathrm{~L}^{-1} \mathrm{SrCl}_{2} ; 0.006 \mathrm{~g} \mathrm{~L}^{-1}$ $\left.\mathrm{H}_{3} \mathrm{BO}_{3}\right)$ ) were inoculated with $10^{5}$ spores of $P$. citrinum, followed by incubation at $30^{\circ} \mathrm{C}$ during 7,14 and 28 days, at an initial $\mathrm{pH}$ 8.0. At the end of growth, cultures were harvested and filtered through celite. The liquid media of identical growth experiments were pooled and subjected to a reversed-phase solid phase extraction using a $\mathrm{C}_{18}$ cartridge eluted with $100 \% \mathrm{H}_{2} \mathrm{O}$ (fraction 1, discarded), 1:1 $\mathrm{MeOH} / \mathrm{H}_{2} \mathrm{O}$ (fraction 2, F2) and $100 \% \mathrm{MeOH}$ (fraction 3, F3). Fractions F2 and F3 were collected, dried in vacuo and weighed. Aliquots of $1 \mathrm{mg}$ of each F2 and F3 were analyzed by HPLC-UV-MS using a reversed-phase $\mathrm{C}_{18}$ column $\left(\mathrm{X}\right.$-Terra $\left.{ }^{\circledR} \mathrm{MS}, 50 \times 2.1 \mathrm{~mm}, 3.5 \mu \mathrm{m}\right)$, eluted with a $\mathrm{MeOH} / \mathrm{H}_{2} \mathrm{O}$ gradient.

$\left[{ }^{13} \mathrm{C}-6,{ }^{13} \mathrm{C}-8,{ }^{13} \mathrm{C}-10,{ }^{13} \mathrm{C}-12,{ }^{13} \mathrm{C}-14\right](8 \mathrm{E})-1-(2,3-$ dihydro- $1 \mathrm{H}-$ pyrrol-1-yl)-2-methyldec-8-ene-1,3-dione (1)

Incolor gum. $5.4 \mathrm{mg}$. Seven relevant ions were detected in the positive mode ESI mass spectrum with $\mathrm{m} / \mathrm{z}$ 250.0, 251.0, 252.0, 253.0, 254.0, 255.0 and 272.0, of which $\mathrm{m} / \mathrm{z}$ 250.0 corresponded to the $[\mathrm{M}+\mathrm{H}]^{+}$ion of unlabeled $\mathbf{1}$ and peaks at $m / z 251.0,252.0,253.0,254.0,255.0$ corresponded to the protonated molecular ions of sodium $\left[1-{ }^{13} \mathrm{C}\right]$ acetate labeled 1. An additional ion detected at $\mathrm{m} / \mathrm{z}, 272.0$ corresponded to sodium adduct ion of unlabeled $\mathbf{1}$. See Figures S2 to S4 (Supplementary Information).

$\left[{ }^{13} \mathrm{C}-6,{ }^{13} \mathrm{C}-8,{ }^{13} \mathrm{C}-10,{ }^{13} \mathrm{C}-12,{ }^{13} \mathrm{C}-14\right]-1-(2,3-d i h y d r o-1 H-$ pyrrol-1-yl)-2-methyldecane-1,3-dione (2)

Incolor gum. $1.1 \mathrm{mg}$. Seven relevant ions were detected in the positive mode ESI mass spectrum with $\mathrm{m} / \mathrm{z}$ 252.0, 253.0, 254.0, 255.0, 256.0, 257.0 and 274.0, 
of which $\mathrm{m} / \mathrm{z} 252.0$ corresponded to the $[\mathrm{M}+\mathrm{H}]^{+}$ion of unlabeled 2 and peaks at $m / z$ 253.0, 254.0, 255.0, 256.0, 257.0 corresponded to the protonated molecular ions of sodium $\left[1-{ }^{13} \mathrm{C}\right]$ acetate labeled 2. An additional ion detected at $\mathrm{m} / \mathrm{z}, 274.0$ corresponded to the $[\mathrm{M}+\mathrm{Na}]^{+}$ion of unlabeled 2 .

$\left[{ }^{13} \mathrm{C}-6,{ }^{13} \mathrm{C}-7,{ }^{13} \mathrm{C}-8,{ }^{13} \mathrm{C}-9,{ }^{13} \mathrm{C}-10,{ }^{13} \mathrm{C}-11,{ }^{13} \mathrm{C}-12,{ }^{13} \mathrm{C}-13\right.$, $\left.{ }^{13} \mathrm{C}-14,{ }^{13} \mathrm{C}-15\right](8 E)-1$-(2,3-dihydro-1 H-pyrrol-1-yl)-2methyldec-8-ene-1,3-dione (1)

Incolor gum. $4.3 \mathrm{mg}$. Seven relevant ions were detected in the positive mode ESI mass spectrum with $\mathrm{m} / \mathrm{z} 250.0$, 252.0, 254.0, 256.0, 258.0, 260.0 and 272.0, of which $\mathrm{m} / \mathrm{z}$ 250.0 corresponded to the $[\mathrm{M}+\mathrm{H}]^{+}$ion of unlabeled $\mathbf{1}$ and $\mathrm{m} / \mathrm{z} 252.0,254.0,256.0,258.0,260.0$ corresponded to the protonated molecular ions of sodium $\left[1,2-{ }^{13} \mathrm{C}_{2}\right]$ acetate labeled 1. An ion detected at $\mathrm{m} / \mathrm{z} 272.0$ corresponded to the $[\mathrm{M}+\mathrm{Na}]^{+}$ion of unlabeled $\mathbf{1}$. See Figures S5 to S10.

$\left[{ }^{13} \mathrm{C}-6,{ }^{13} \mathrm{C}-7,{ }^{13} \mathrm{C}-8,{ }^{13} \mathrm{C}-9,{ }^{13} \mathrm{C}-10,{ }^{13} \mathrm{C}-11,{ }^{13} \mathrm{C}-12,{ }^{13} \mathrm{C}-13,{ }^{13} \mathrm{C}-14\right.$, $\left.{ }^{13} \mathrm{C}-15\right] 1$-(2,3-dihydro-1 H-pyrrol-1-yl)-2-methyldecane-1,3dione (2)

Incolor gum. $1.0 \mathrm{mg}$. Seven relevant ions were detected in the positive mode ESI mass spectrum with $\mathrm{m} / \mathrm{z}$ 252.0, 254.0, 256.0, 258.0, 260.0, 262.0 and 274.0, of which $\mathrm{m} / \mathrm{z}, 252.0$ corresponded to the $[\mathrm{M}+\mathrm{H}]^{+}$ion of unlabeled 2 while ions at $\mathrm{m} / \mathrm{z}$ 254.0, 256.0, 258.0, 260.0, 262.0 corresponded to the protonated molecular ions of sodium $\left[1,2-{ }^{13} \mathrm{C}_{2}\right]$ acetate labeled $\mathbf{2}$. An ion detected at $\mathrm{m} / \mathrm{z}$ 274.0 corresponded to the sodium adduct of unlabeled $\mathbf{2}$.

$\left[{ }^{13} \mathrm{C}-16\right](8 E)-1-(2,3-d i h y d r o-1 H$-pyrrol-1-yl)-2-methyldec-8ene-1,3-dione (1)

Incolor gum. $4.0 \mathrm{mg}$. Four relevant ions were detected in the positive mode ESI mass spectrum with $\mathrm{m} / \mathrm{z} 250.0$, 272.0, 251.0 and 273.0, of which $\mathrm{m} / \mathrm{z}, 250$ and 272.0 corresponded to the unlabeled $[\mathrm{M}+\mathrm{H}]^{+}$and $[\mathrm{M}+\mathrm{Na}]^{+}$ions of $\mathbf{1}$, respectively. Ions detected at $\mathrm{m} / \mathrm{z} 251.0$ and 273.0 corresponded to the protonated molecular ion and to the sodium adduct ion of $\left[\right.$ methyl $\left.-{ }^{13} \mathrm{C}\right]$ methionine labeled $\mathbf{1}$, respectively. See Figures S11 and S12.

$\left[{ }^{13} \mathrm{C}-16\right] 1$-(2,3-dihydro-1 H-pyrrol-1-yl)-2-methyldecane-1,3dione (2)

Incolor gum. $1.0 \mathrm{mg}$. Four relevant ions were detected in the positive mode ESI mass spectrum with $\mathrm{m} / \mathrm{z}$ 252.0, 274.0, 253.0 and 275.0, of which $\mathrm{m} / \mathrm{z} 252.0$ and 274.0 corresponded to the unlabeled $[\mathrm{M}+\mathrm{H}]^{+}$and $[\mathrm{M}+\mathrm{Na}]^{+}$ ions of 2, respectively. Ions detected at $\mathrm{m} / \mathrm{z} 253.0$ and 275.0 corresponded to $[\mathrm{M}+\mathrm{H}]^{+}$and $[\mathrm{M}+\mathrm{Na}]^{+}$ions of $\left[\right.$ methyl $\left.-^{13} \mathrm{C}\right]$ methionine labeled $\mathbf{2}$. $\left[{ }^{13} \mathrm{C}-2,{ }^{13} \mathrm{C}-3,{ }^{13} \mathrm{C}-4,{ }^{13} \mathrm{C}-5\right](8 E)-1$-(2,3-dihydro- $1 \mathrm{H}$-pyrrol1-yl)-2-methyldec-8-ene-1,3-dione (1)

Incolor gum. $7.5 \mathrm{mg}$. Four relevant ions were detected in the positive mode ESI mass spectrum with $\mathrm{m} / \mathrm{z} 250.0,272.0$, 254.0 and 276.0 , of which $\mathrm{m} / \mathrm{z} 250.0$ and 272.0 corresponded to the $[\mathrm{M}+\mathrm{H}]^{+}$and $[\mathrm{M}+\mathrm{Na}]^{+}$ions of unlabeled $\mathbf{1}$, and the ions at $\mathrm{m} / \mathrm{z} 254.0$ and 276.0 corresponded to the $[\mathrm{M}+\mathrm{H}]^{+}$and $[\mathrm{M}+\mathrm{Na}]^{+}$ions of $\left[\mathrm{U}_{-}{ }^{13} \mathrm{C}_{5}\right]$ ornithine labeled $\mathbf{1}$. See Figures S13 to S16.

$\left[{ }^{13} \mathrm{C}-2,{ }^{13} \mathrm{C}-3,{ }^{13} \mathrm{C}-4,{ }^{13} \mathrm{C}-5\right] 1-(2,3-$ dihydro- $1 \mathrm{H}-$ pyrrol-1-yl)-2methyldecane-1,3-dione (2)

Incolor gum. $2.1 \mathrm{mg}$. Four relevant ions were detected in the positive mode ESI mass spectrum with $\mathrm{m} / \mathrm{z} 252.0$, 274.0, 256.0 and 278.0, of which $\mathrm{m} / \mathrm{z} 252.0$ and 274.0 corresponded to the $[\mathrm{M}+\mathrm{H}]^{+}$and $[\mathrm{M}+\mathrm{Na}]^{+}$ions of unlabeled 2 , while $\mathrm{m} / \mathrm{z} 256.0$ and 278.0 corresponded to the $[\mathrm{M}+\mathrm{H}]^{+}$and $[\mathrm{M}+\mathrm{Na}]^{+}$ions of $\left[\mathrm{U}-{ }^{13} \mathrm{C}_{5}\right]$ ornithine labeled $\mathbf{2}$.

\section{Supplementary Information}

ESI-MS and ${ }^{13} \mathrm{C}$ NMR spectra of all ${ }^{13} \mathrm{C}$-labeled compounds are available free of charge athttp://jbcs.sbq.org.br as a PDF file.

\section{Acknowledgments}

The authors thank Prof. Mirna H. R. Seleghim (DEBE, UFSCar) for many facilities provided for microbiological experiments. Financial support was provided by Fundação de Amparo à Pesquisa do Estado de São Paulo (FAPESP) to R. G. S. B. (2009/51199-6) and E. F. P. (2010/05100-5), as well as by CNPq (142116/2009-2) to S. R..

\section{References}

1. Dewick, P. N.; Medicinal Natural Products; a Biosynthetic Approach, John Wiley \& Sons: Chichester, 2009, ch. 6, pp. 309-324.

2. Faulkner, D. J.; Carté, B.; J. Org. Chem. 1983, 48, 2314.

3. Lindquist, N.; Fenical, W.; Experientia 1991, 47, 504.

4. Blackman, A. J.; Li, C. P.; Aust. J. Chem. 1994, 47, 1625.

5. Rapoport, H.; Holden, K. G.; J. Am. Chem. Soc. 1960, 82, 5510.

6. Devlin, J. P.; Edwards, O. E.; Gorham, P. R.; Hunter, N. R.; Pike, R. K.; Stavric, B.; Can. J. Chem. 1977, 55, 1367.

7. Braekman, J. C.; Daloze, D.; Pasteels, J. M. In Alkaloids: Biochemistry, Ecology, and Medicinal Applications; Roberts, M. F.; Wink, M.; Plenum Press: New York, 1998, ch. 15, pp. 354-360.

8. Scifinder; http://www.cas.org/products/scifinder accessed in September, 2012; The Dictionary of Natural Products; 
http://dnp.chemnetbase.com accessed in September, 2012; Cole, R. J.; Schweikert, M. A.; Handbook of Secondary Fungal Metabolites, Academic Press: San Diego and London, 2003, vols. 1-3.; Mander, L.; Liu, H.-W.; Comprehensive Natural Products II: Chemistry and Biology, Elsevier Science: Amsterdam, 2010, vols. 1-10.

9. McCorkindale, N. J.; Baxter, R. L.; Tetrahedron 1981, 37, 1795.

10. Moya, P.; Cantin, A.; Castillo, M.-A.; Primo, J.; Miranda, M. A.; Primo-Yufera, E.; J. Org. Chem. 1998, 63, 8530.

11. Cantin, A.; Moya, P.; Castillo, M.-A.; Primo, J. E.; Miranda, M. A.; Primo-Yufera, E.; Eur. J. Org. Chem. 1999, 221.

12. Castillo, M.-A.; Moya, P.; Cantin, A.; Miranda, M. A.; Primo, J.; Hernandez, E.; Primo-Yufera, E.; J. Agric. Food Chem. 1999, 47, 2120.

13. Tsuda, M.; Sasaki, M.; Mugishima, T.; Komatsu, K.; Sone, T.; Tanaka, M.; Mikami, Y.; Kobayashi, J.; J. Nat. Prod. 2005, 68, 273.

14. Sasaki, M.; Tsuda, M.; Sekiguchi, M.; Mikami, Y.; Kobayashi, J.; Org. Lett. 2005, 7, 4261.

15. Pimenta, E. F.; Vita-Marques, A. M.; Tininis, A.; Seleghim, M. H. R.; Sette, L. D.; Veloso, K.; Ferreira, A. G.; Williams, D. E.; Patrick, B. O.; Dalisay, D. S.; Andersen, R. J.; Berlinck,
R. G. S.; J. Nat. Prod. 2010, 73, 1821.

16. Burke, C.; Thomas, T.; Egan, S.; Kjelleberg, S.; Environ. Microbiol. 2007, 9, 814.

17. Cerdeño, A. M.; Bibb, M. J.; Challis, G. L.; Chem. Biol. 2001, $8,817$.

18. Kubanek, J.; Andersen, R. J.; J. Nat. Prod. 1999, 62, 777.

19. Brock, M.; Buckel, W.; Eur. J. Biochem. 2004, 271, 3227.

20. Brock, M.; Fischer, R.; Linder, D.; Buckel, W.; Mol. Microbiol. 2000, 35, 961.

21. Zhang, Y.-Q.; Brock, M.; Keller, N. P.; Genetics 2004, 168, 785.

22. Gill, M.; Gimenez, A.; J. Chem. Soc., Perkin Trans. 11990 , 1159.

23. Steyn, P. S.; Vleggaar, R.; J. Chem. Soc., Chem. Commun. 1984, 977.

24. Griffin, D. H.; Fungal Physiology, Wiley-Liss, Inc.: New York, 1994, pp. 228-233.

Submitted: May 3, 2012

Published online: September 28, 2012

FAPESP has sponsored the publication of this article. 